\title{
SUMMER URBAN HEAT ISLAND OF GALAT,I CITY (ROMANIA) DETECTED USING SATELLITE PRODUCTS
}

\author{
Crețu Ștefănel - Claudiu ${ }^{1}$, Ichim Pavel ${ }^{1,2 *} \mathbb{1}$, Sfîcă Lucian ${ }^{1}$ (i) \\ ${ }^{1}$ Alexandru Ioan Cuza University of Iași e-mail: cretuclaudiu861@yahoo.com \\ ${ }^{2}$ Romanian Young Academy (RYA), University of Bucharest, Romania \\ * Corresponding author: pavel_ichim@yahoo.com
}

Keywords: urban heat island, urban canopy, surface temperature, UHI intensity

\begin{abstract}
The paper presents the main features of the urban heat island of Galați city during the summer season for a period of 16 years (2003-2018) using MODIS products. The main objectives were to analyse the extension and geometry of the urban heat island (UHI), its intensity, as well as its connection with land cover. The study is based on LST (Land Surface Temperature), a product obtained from Moderate Resolution Imaging Spectroradiometer (MODIS) sensors located on board of the Terra (EOS AM-1) satellite since 2001 and Aqua (EOS PM-1) satellite since 2003. The boundaries, geometry and spatial extent of the UHI were delimited primarily through the Rodionov test. Through this method, the changing points along four transects over Galati city were identified (North-South, EastWest, Northeast-Southwest and Northwest-Southeast) and have been used to delimitate the UHI.

Overall, the Galați UHI assessed by satellite information is stronger during the day when the UHI is split in two centres, developed over the industrial area in the west and over the residential part of the town in the east, while during the night the UHI is weaker being developed more clearly over the oldest part of the city. One of the major characteristics of the Galati UHI is that it is highly influenced by the water bodies encircling the city. During the day the intensity of UHI reaches $2-2.5^{\circ} \mathrm{C}$ while during the night decreases below $2.0^{\circ} \mathrm{C}$. The relation of the UHI with land cover and the attenuation of UHI in the surrounding area are also investigated.
\end{abstract}

\section{Introduction}

Urbanization exerts a very complex action on the climate, both by the appearance of artificial surfaces, and by the changes of the energy fluxes at ground level. The effect of urbanization is synthetized from a climatic point of view by the Urban Heat Island (UHI). UHI is the term associated with the thermal difference between urban and rural areas, being defined in several ways (Schwarz et al., 2011).

Generally, two methods have been developed for the assessment of UHI intensity. Firstly, UHI can be quantified by cross-sectional measurements through 
the city, usually $2 \mathrm{~m}$ above the ground, the temperature values from the inner city being compared with those in neighbouring rural areas (Arnfield, 2003; Stewart, 2011). Secondly, UHI can be quantified through remote sensing (Voogt \& Oke, 2003). The quantification of UHI through remote sensing involves the use of LST (Land Surface Temperature) that, unlike the fixed points measurements, is more accurate from a spatial point of view. Of course, the effect of UHI depends on several factors such as topography, city surface, altitude above sea level, latitude but also atmospheric stability (Wienert \& Kuttler, 2005).

The effects of UHI manifestation are felt at the urban level and at the building level, through discomfort and implicitly through the increase of energy required for air conditioning and mechanical ventilation, which leads to greenhouse gas emissions (Zhou et al., 2010a; Zhou \& Gurney, 2010b). The temperature in the urban environment can be higher than in the rural area in any season, but the striking impact occurs in the summer season, when the UHI amplifies the natural warming of the atmosphere leading to serious consequences for the life of the urban population (Basara et al. 2010; Tan et al. 2010; Gabriel \& Endlicher 2011). Moreover, rapid urbanization and global climate change lead to the exposure of the city population to the risk of heat waves (Zhou et al., 2010a, 2010b; Yang et al., 2017). With regard to the increase of possible dangers caused by UHI, more and more attention is paid to this subject, the precise quantification of UHI leading to the correct risk assessment and guidance of the cities management and development.

From the first observations on the urban heat island by Howard in London (Mills, 2008) this phenomenon has been studied for cities of different sizes (Arnfield, 2003; Zhang et al., 2008; Zhou et al., 2010a, 2010b; Tan, 2010; Schwarz, 2011). Studies on the UHI have been carried out mainly for the largest cities in Romania using MODIS products (Cheval \& Dumitrescu 2009a; Cheval et. al. 2009b; Macarof, 2017). Other studies were based on air temperature observations for long periods (Sfîcă et al., 2017a) or by expeditionary observations using transect method during a strong heat wave (Apostol et. al. 2012). In such conditions an intensity of $3-4{ }^{\circ} \mathrm{C}$ of nocturnal UHI was measured (Ichim et. al, 2018). For the city of Iași Sfîcă et al. (2017a) calculated an average intensity of UHI for the period 2012-2015 of $0.8{ }^{\circ} \mathrm{C}$. The largest temperature difference between the city center and the surroundings area was observed during the night especially in the summer season when the intensity of UHI reaches $2.5-3^{\circ} \mathrm{C}$.

Few climate studies have been carried out for the city of Galați. The effect of the urban heat island of Galați city was analyzed by Gugiuman 1975, and Florea, 2000, and consisted in highlighting the limit of influence of the UHI and its extension. None of the studies on the urban climate of the Galați city was carried out using satellite images. Therefore, the current study aims to describe the main 
features of Galați UHI during summer using satellite products for 16 years of observations.

\section{STUDY AREA}

The city of Galați is located in the eastern part of Romania, at $45^{\circ} 27$ " $\mathrm{N}$ and $28^{\circ} 02$ " E. Extended on the left bank of the Danube, the city it's extended over an area of $241.5 \mathrm{~km}^{2}$, between the confluence of the rivers Siret (west) and Prut (east), near Brates Lake. The existing urban area of the municipality includes an area of 5,856.43 ha, and the surface of the administrative territory is $24.363,37$ ha, including Lake Brateș with an area of 2.400 ha, as indicated by our assessment based on Urban Atlas data (Copernicus Land Monitoring Service, 2018).

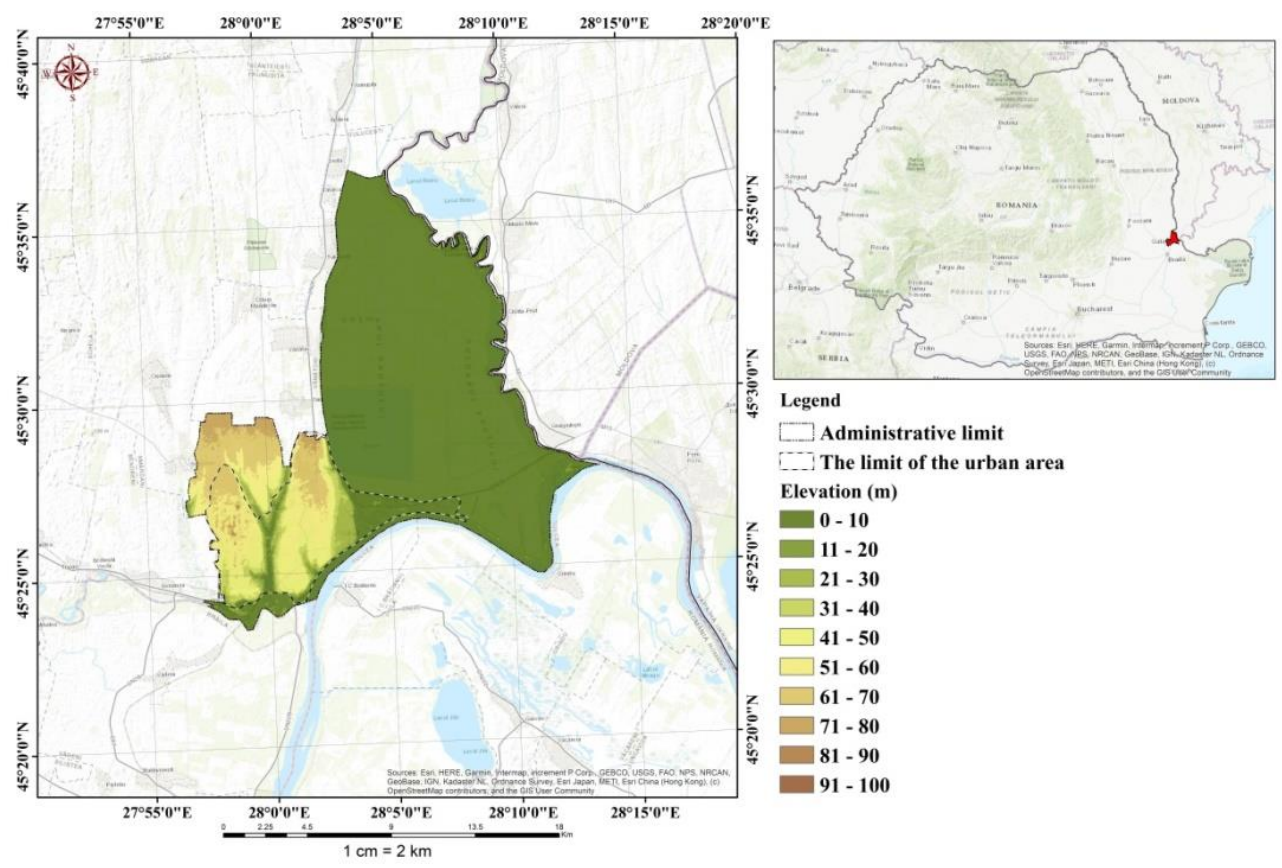

Figure 1 The Geographical Location of Galați City

The municipality of Galați has a population of about 249.432 inhabitants according to the 2011 census. The stable population of the municipality represents approximately $43.12 \%$ of the population of the county. Relating the population of the municipality to its surface, the density is 938.33 inhabitants $/ \mathrm{km}^{2}$ (Development strategy of Galați municipality 2016-2025). 


\section{DATASETS AND METHODOLOGY}

3.1. Datasets. As part of NASA's international Earth observation system, two MODIS platforms have been launched to provide information for global studies of atmospheric, terrestrial and ocean processes. The first instrument was launched on December 18, 1999 on the platform called Terra, and the second was launched on May 4, 2002 on the platform called Aqua. The crossing local time of Romania for the Terra platform is around 10:30 AM on the downward trajectory and $10 \mathrm{PM}$ on the upward trajectory and for Aqua the crossing time is around 1:30 PM upward trajectory and 1:30 AM downward trajectory (Leiqiu Hu et al. 2013).

Among the products delivered by these sensors is Land Surface Temperature (LST), one of the key parameters in the physics of land surface processes on a regional and global scale. It combines the results of all the interactions between the earth's surface and the atmosphere as well as the energy balance between the atmosphere and the ground (Wan et al., 2004, Zhang, et al. 2008).

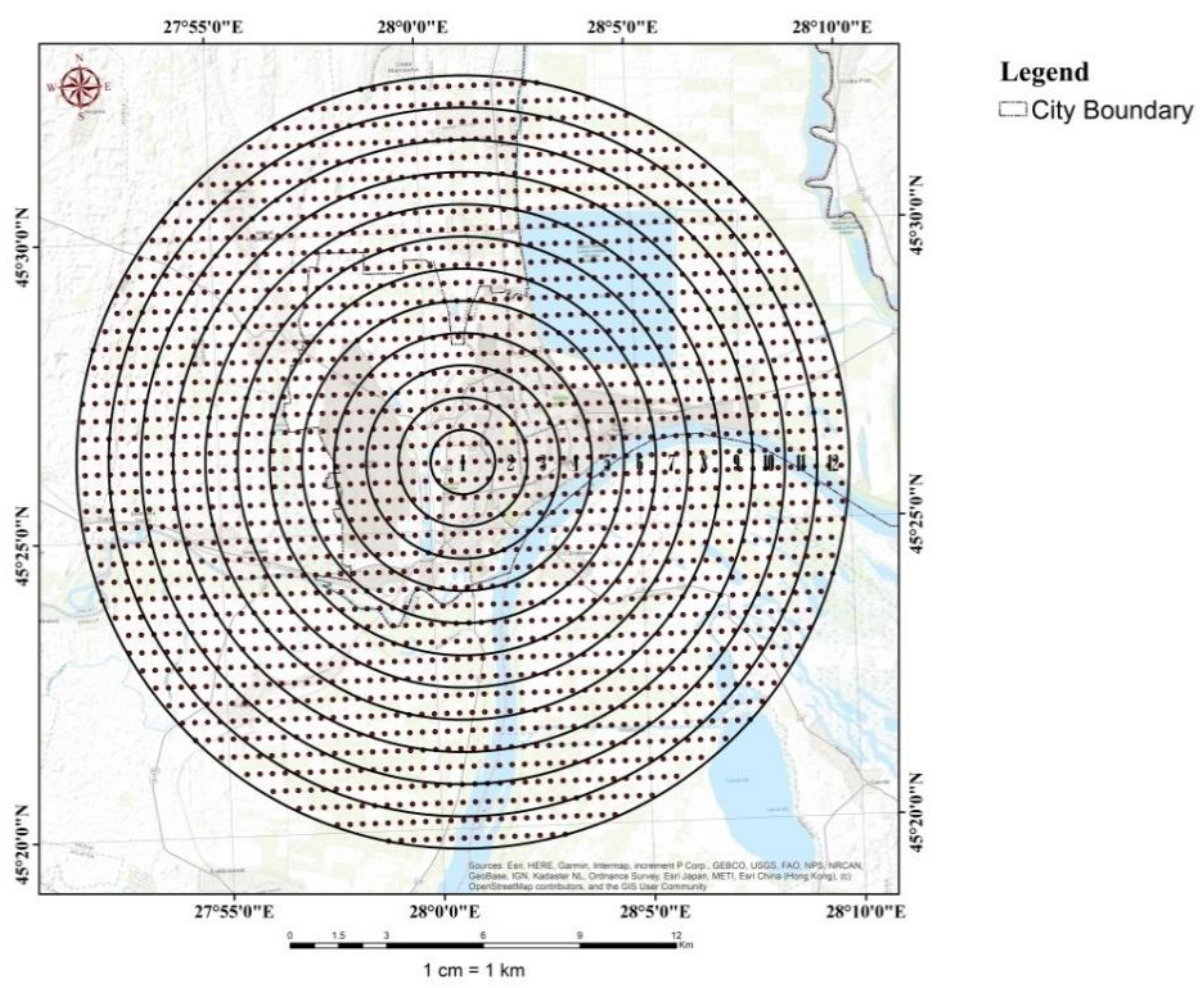

Figure 2 Buffer and grid points used for Galaţi UHI assessment 
Two of the data sets, provided by ORNL DAAC-Collection-6 MODIS Land Surface Temperature Products, were used for this study, MOD11A2-MODIS global, LST and Emissivity 8-day (MODIS-Terra) and MYD11A2 respectively MODIS global LST and 8-day Emissivity (MODIS-Aqua). These datasets are LST products based on the calculation of the mean for two to eight days (Wan, 2015a; $2015 b ; 2015 c)$.

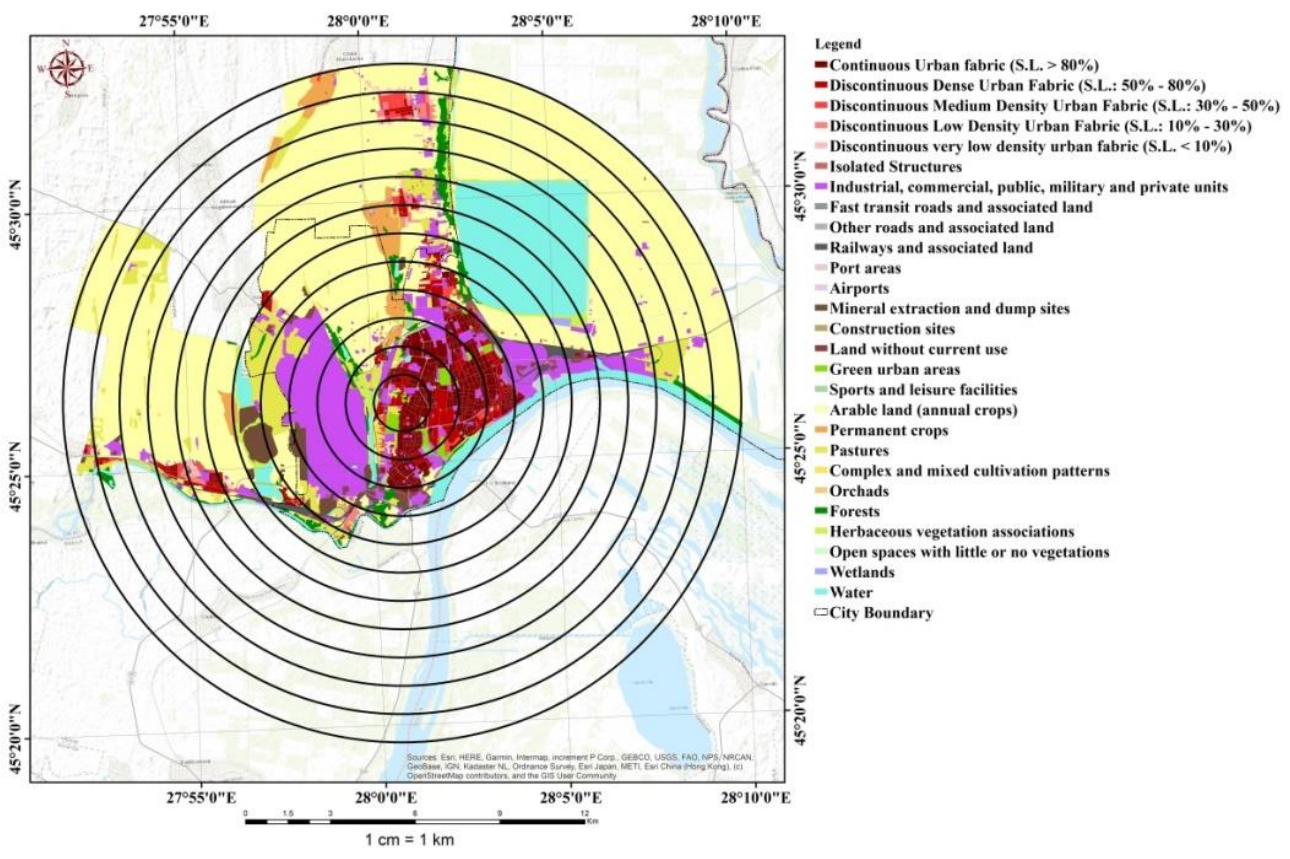

Figure 3 Urban Atlas land cover categories for Galați city region

For the beginning, the images for the summer season were selected, starting with June 2003 and ending with August 2018. The next step was to design a buffer zone with a stretch of up to $12 \mathrm{~km}$ starting from the inner city of the urban area (fig.2), similarly as in Cheval et al. (2009a). An important condition for the selection of images was related to the absence of cloud cover over the region. Clouds absorb long-wave radiation, thus blocking LST observations (Williamson et al., 2013). Thus, only images that showed all valid pixels within the buffer area were selected. The two data sets include two LST images, one taken during the day and one taken during the night, with a resolution of approximately $1 \mathrm{~km}$ (LP DAAC, 2013). This way, the 8-day mean, monthly mean, multiannual monthly mean, seasonal mean and then multiannual seasonal mean were calculated for each 
data set. At the end, the Aqua and Terra images during the night were averaged. A similar procedure was applied for the daytime images. Consequently, from the Terra data set 355 images during the day and 350 at night were used, respectively 348 images during the day and 347 at night for the Aqua data set. These represent in fact all the satellite images with less than $20 \%$ cloud cover during summer for 2002-2018.

In this paper, Urban Atlas (2012) data were used for land cover. The Urban Atlas provides pan-European comparable land use and land cover data for Functional Urban Areas (FUA). The Urban Atlas is a joint initiative of the European Commission Directorate-General for Regional and Urban Policy and the Directorate-General for Enterprise and Industry in the frame of the EU Copernicus program with the support of the European Space Agency and the European Environment Agency (fig. 3).

3.2. Methodology. Using QGis 3.10.2, to improve spatial resolution from 1 $\mathrm{km}$ to $500 \mathrm{~m}$, multiannual monthly mean and multiannual seasonal mean images (for both day and night) were regrinding using the bilinear interpolation method. Regrinding is the process of interpolating from one grid resolution to a different grid resolution. The most commonly used methods of climate grid interpolation are bilinear, conservative and patch. The bilinear method is easy to program and apply when the source and destination grids are rectilinear. For smoothly varying variables, bilinear interpolation is adequate for many applications (Climate Data Guide, UCAR - Analysis Tools and Methods).

After bilinear interpolation, a grid system was created, for each point corresponding to the center of every pixel (fig.4). Using this point system, the temperature values were extracted from the images and interpolated using Kriging method (Patriche, 2009). The results proved to be much clearer from a spatial point of view as opposed to the initial ones, especially when highlighting the limits of UHI. Also, to calculate the temperature differences between the urban, rural, agricultural and water surface, the points (pixels) specific to these surfaces were selected (fig.4). In addition, 4 transects were designed following the N-S, E-V, NESV and NV-SE directions. They will present the distribution of mean temperatures values across the city as well as the changing points obtained by applying the test proposed by Rodionov (2004).

In the first step in order to highlight the boundaries geometry and spatial extension of the UHI, the points of change along the 4 transects were identified by applying the Rodionov test ( $p>0.1$, cut-off $=10)$. In addition to the fact that the Rodionov test assumes that each data point is independent of the other measurements, it is based on the sequential application of the Student's t test to detect significant changes in the mean regime within a data set (Rodionov, 2004). 
Secondly, it was considered as the limit of the UHI the isotherm that follows the average LST calculated for the center points of each pixel belonging to the urban area additioned by the standard deviation of LST (Rodionov 2004, Cheval and Dumitrescu 2009a).

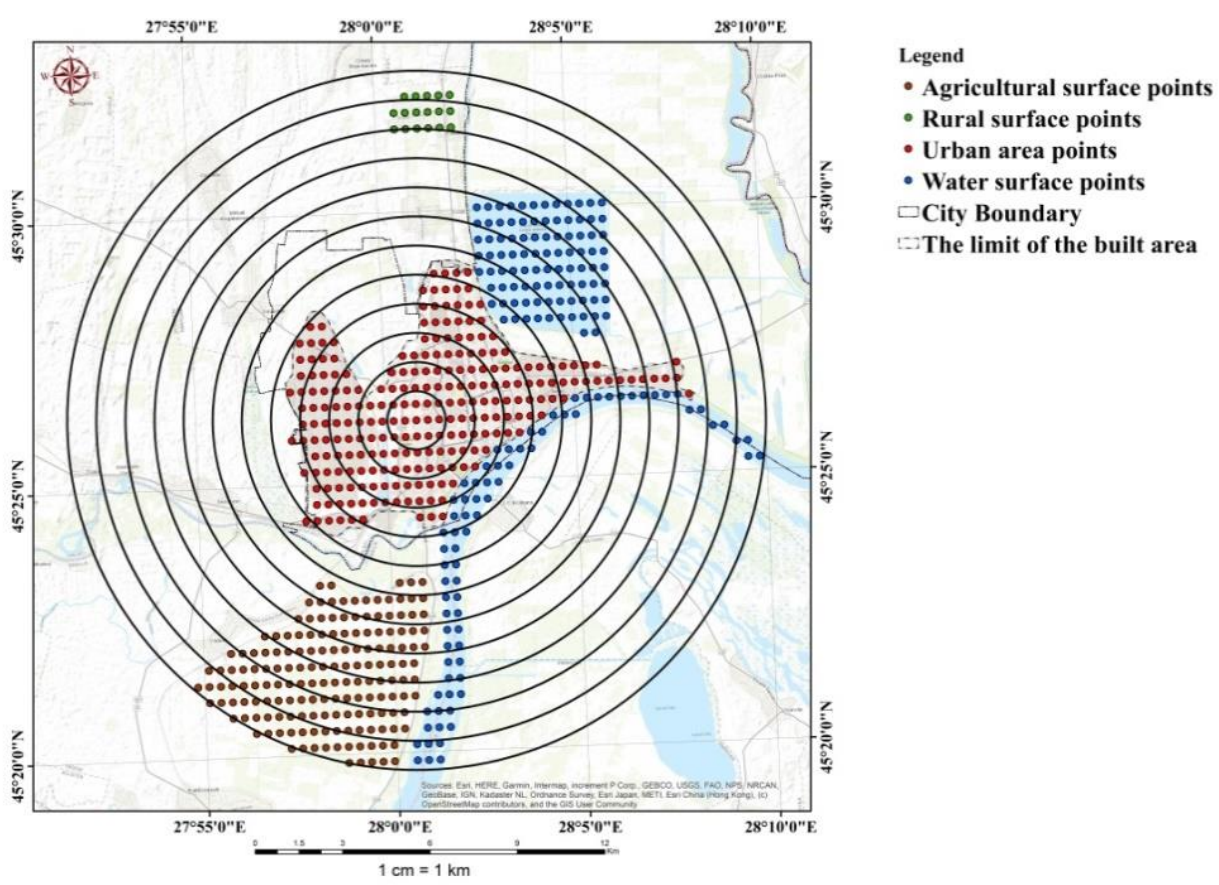

Figure 4 Urban Atlas simplified land use categories weighted by grid point

In the literature, on this topic, the thermal differences between the urban surface and other surfaces such as rural (Imhorff et al., 2010; Zhang et al., 2010), aquatic (Zhou et al., 2010a) or agricultural (Jin et al., 2005) are frequently used to describe the intensity of UHI. Therefore, to quantify the intensity of the UHI, a series of buffers from 1 to $12 \mathrm{~km}$ around the center of the urban area were used, similarly to (Cheval and Dumitrescu 2009a) trying to provide a relevant perspective on temperature differences as we move away from the inner city.

\section{RESULTS AND DISCUSSION}

\subsection{Boundaries and geometry of the Galati summer UHI}

The highest intensity of UHI during summer is generated during the heat waves (HWs) and warm spells (WSs) that are generally cloudless and therefore most of these days are covered with satellite information. During summer the 
highest frequency of HWs/WSs (40\%) was recorded in the last 15 years (Sfîcă et. al., 2017b). HWs/WSs are characterizes by temperatures over $35^{\circ} \mathrm{C}$ during summer in lowlands of Romania (Sfîcă et. al., 2017b) being strongly amplified in urban areas (Ichim et al., 2015).

For daytime (fig.5) observations, we noticed that the LST product realistically highlights the temperature differences between the urban area and its surroundings. Figure 6 shows the variation of the mean LST along N-S, W-E, NE-SW and NW$\mathrm{SE}$ transects during the day and the shifting points retrieved by the Rodionov test.

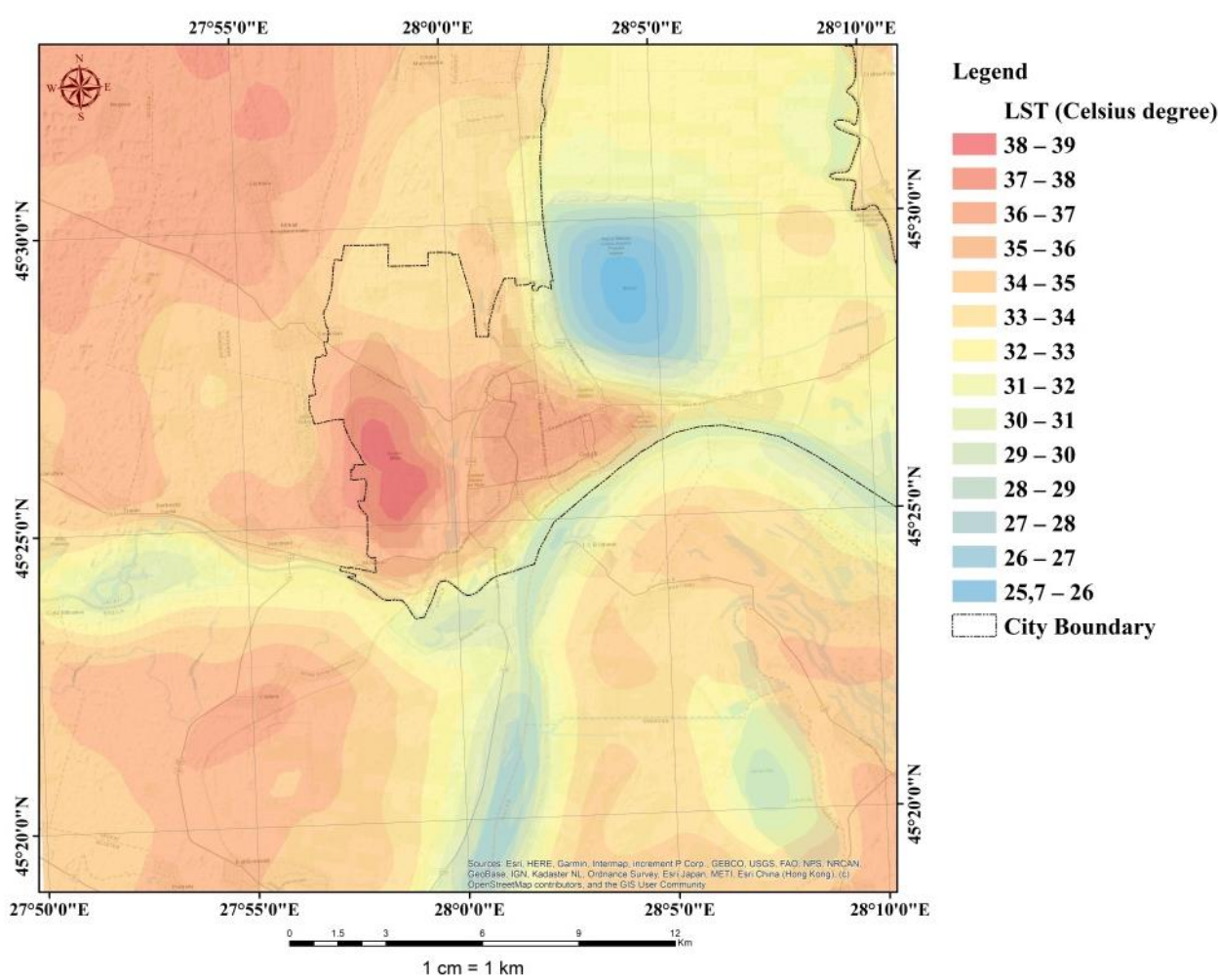

Figure 5 Summer daytime mean LST values $\left({ }^{\circ} \mathrm{C}\right)$ in Galați city region

It is obvious that the factor that plays the most important role in defining the boundaries, geometry and spatial extension of the UHI is the land use and geographical features of the territory. For the daytime, under the influence of the largest industrial area from the western part of the city a strong UHI core develops. This can be clearly observed on the E-W profile in the Figure 6 where LST mean 


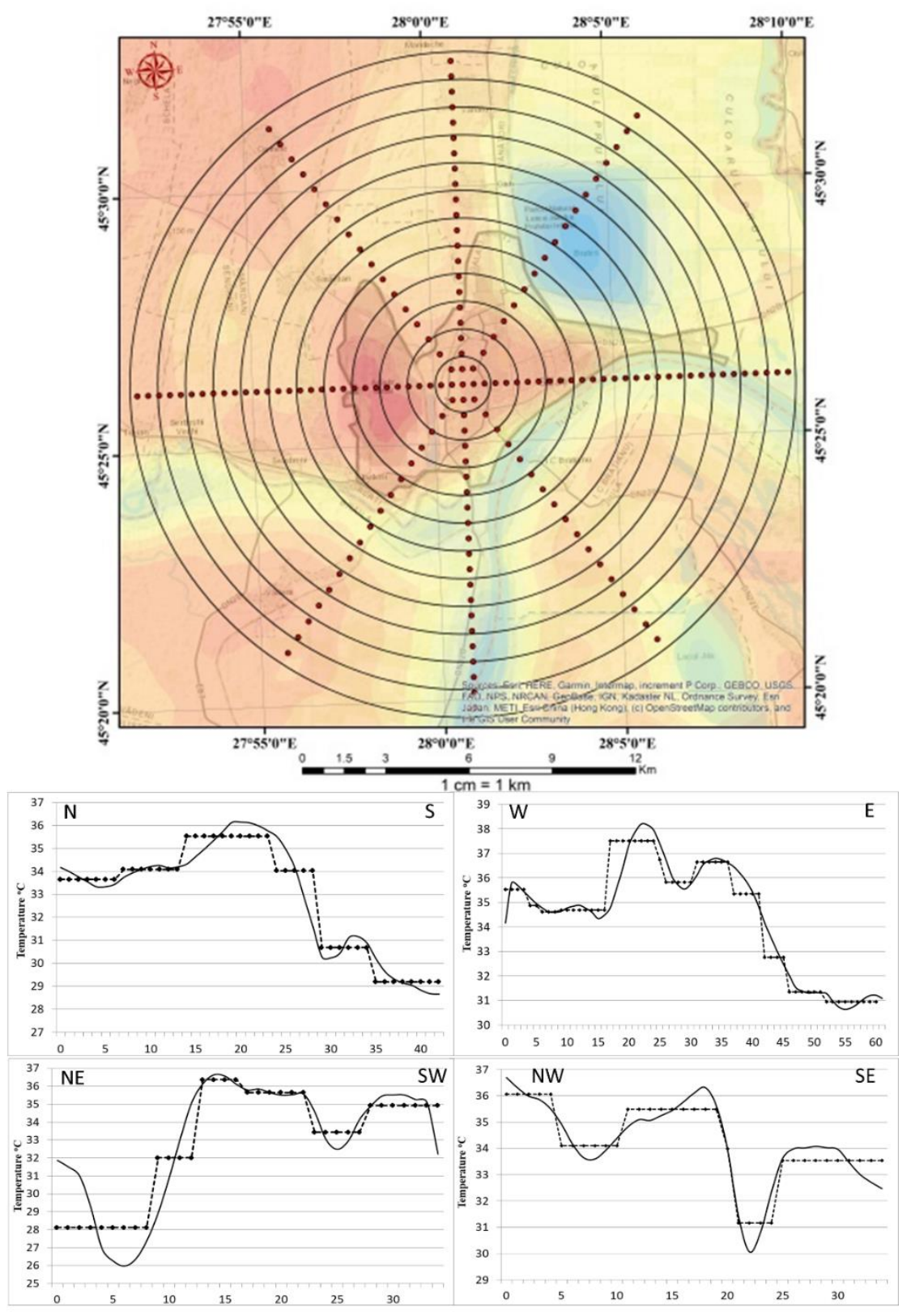

Figure 6 Mean LST profiles across the Galați city for daytime conditions and the UHI shifting points identified using Rodionov test for N-S, E-W, NE-SW and NW-SE transect 
values are highest over the industrial area $\left(37.5^{\circ} \mathrm{C}\right)$. A secondly UHI core is developed over the historical center of the city. This core is observed on the N-S profile in Figure 6 with its peak at $35.5^{\circ} \mathrm{C}$, but also on the NE-SW profile where it shows a mean value at $36.5^{\circ} \mathrm{C}$.

The daytime UHI limit tends to be regular, and average LST within the Galati urban area may reach $35-37^{\circ} \mathrm{C}$, compared with $30-32{ }^{\circ} \mathrm{C}$ in the periurban areas. We should mention that the surrounding water bodies are capable to emphasize the UHI boundaries by the thermal contrast that they impose. In this manner we can detect that the difference during the days between Brateș Lake and the industrial UHI core reaches $10^{\circ} \mathrm{C}$ (Figure 5).

In order to summarize the UHI main features we have tried to identify more precisely the limits of UHI. Thus, the limit of the UHI was considered the isotherm given by mean LST calculated for the points/pixels belonging to the urban area considered the warmest area of the UHI - additioned by the standard deviation of the LST (Figure 7).

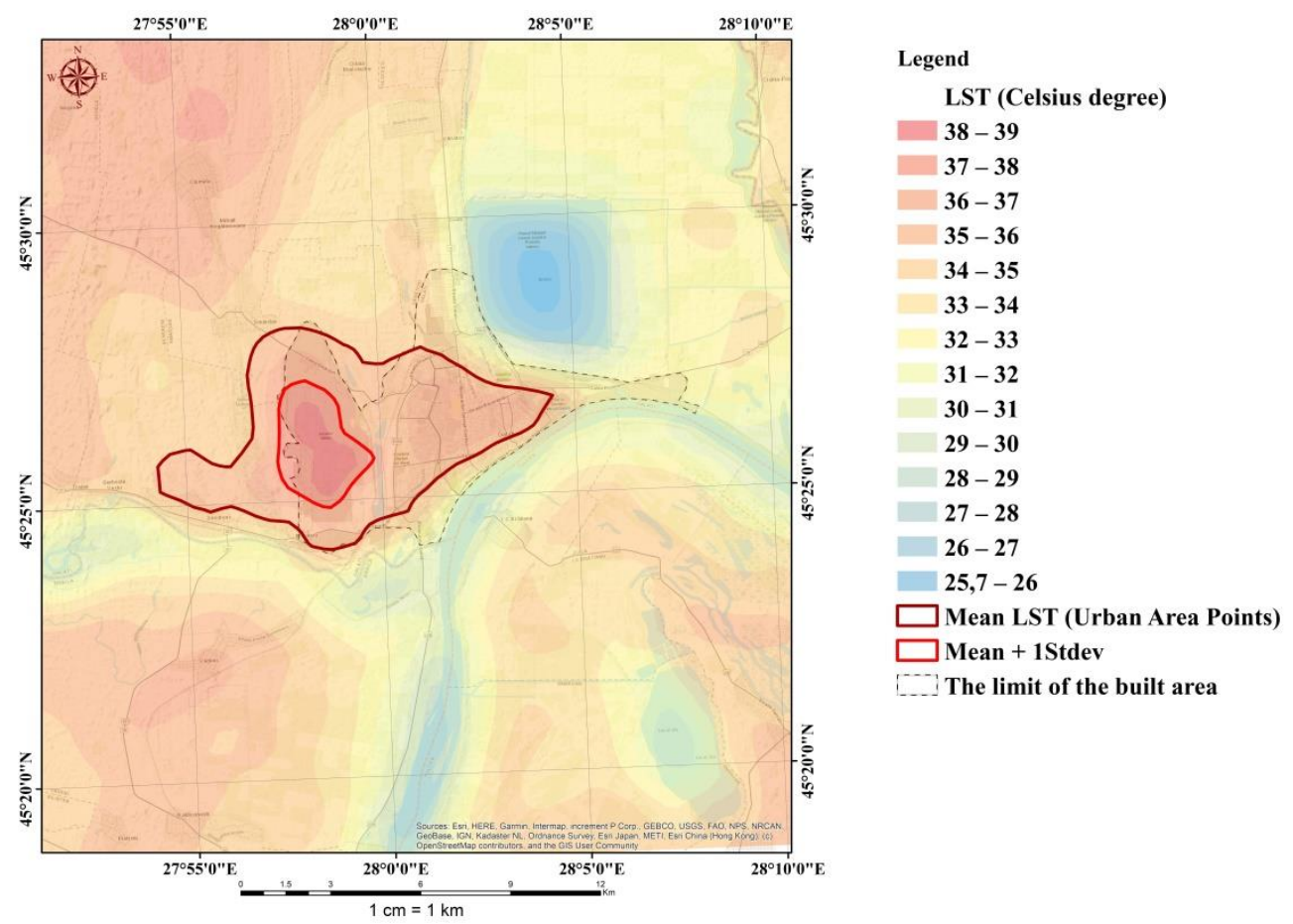

Figure 7 Daytime UHI limits 
In this way the industrial core of Galați summer UHI contribute to the amplification of the UHI represented by the historical and residential parts of the city. Overall, it is easy remarkable that the industrial core of UHI is stronger during this period of the day due to the intense radiative warming of artificial surfaces. It is known that SIDEX industrial platform is one of the most extended industrial area of the entire Romania and it's located not so far from to the residential area so that it can influence the general feature of the urban climate.

During the night (Fig. 8), the UHI limit tends to be a bit more irregular depending on the interpolation algorithm. The irregular UHI extension is due to the water surfaces that emit the heat stored during the day, thus recording temperatures even higher than the city.

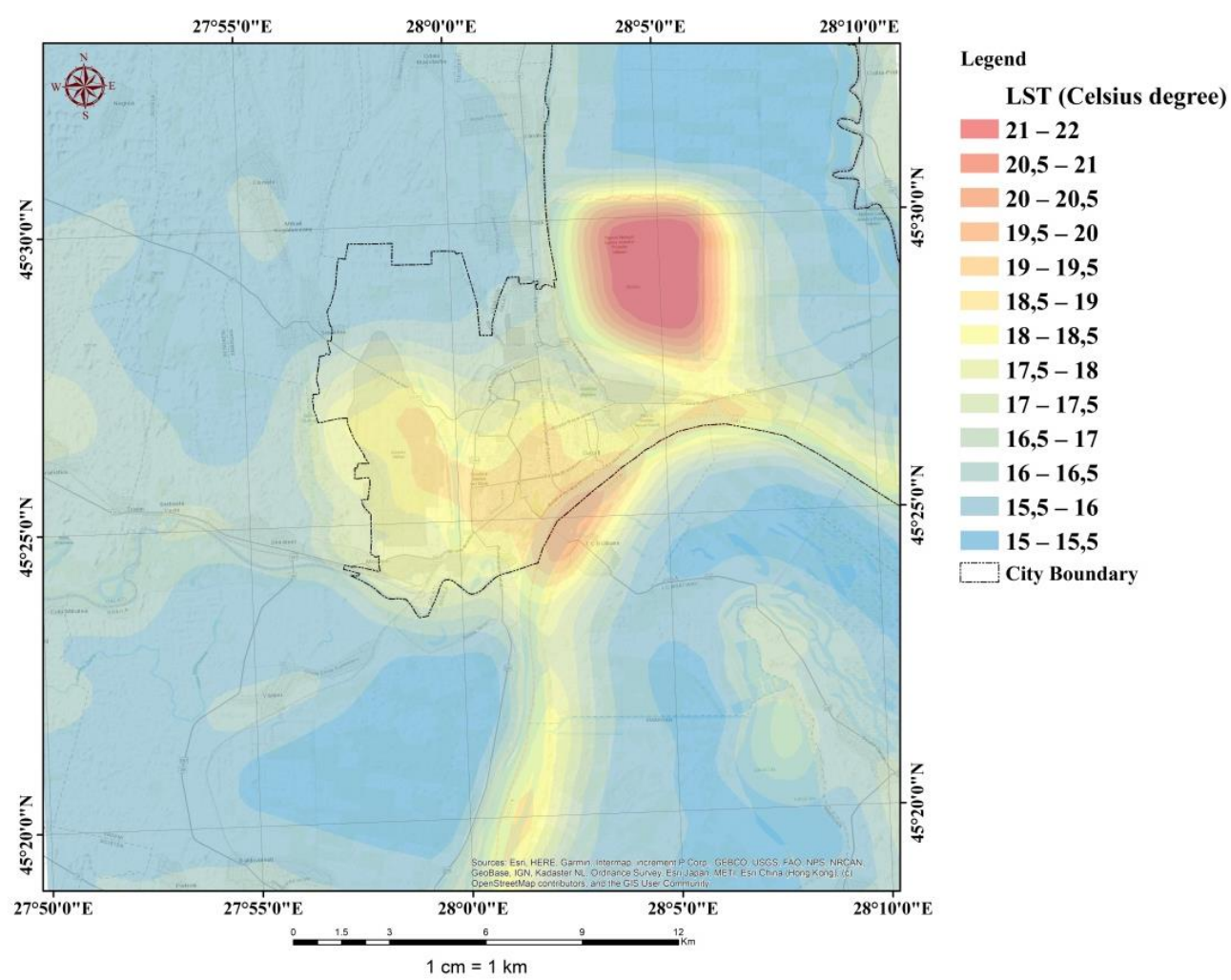

Figure 8 Summer nighttime mean LST values $\left({ }^{\circ} \mathrm{C}\right)$ in Galați city region

Also, due to the city position at the confluence of Danube with Siret, the most important tributary in Romania, one should remark a very interesting case of 


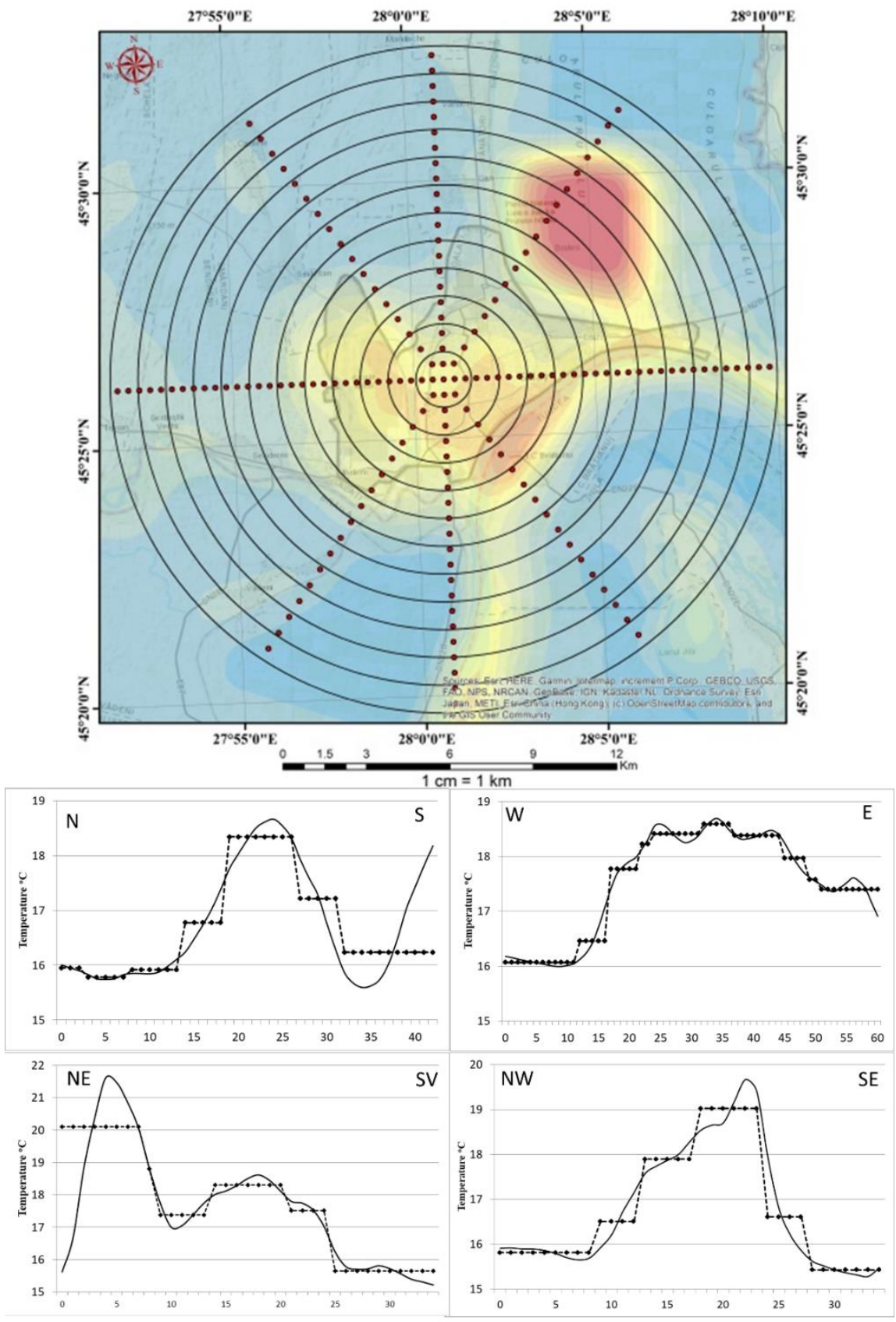

Figure 9 Variation of the mean LST and the shifting points (nighttime) 
interaction between Galați UHI and river temperature. During the nighttime (Figure 8) the Danube surface is very warm exactly along the residential part of the city. In the same time we can observe that the waters brought by Siret river cool the Danube at their confluence $\left(17-18^{\circ} \mathrm{C}\right)$. After that, these cooler waters are probably sinking in depth of the river due to their increased density, while the upper water layers of the Danube in the region of Galați city reaches a maximum in LST $\left(20-21^{\circ} \mathrm{C}\right)$. Also, we should remark that the Danube is more larger in this sector contributing to the warming of these shallower waters of the river.

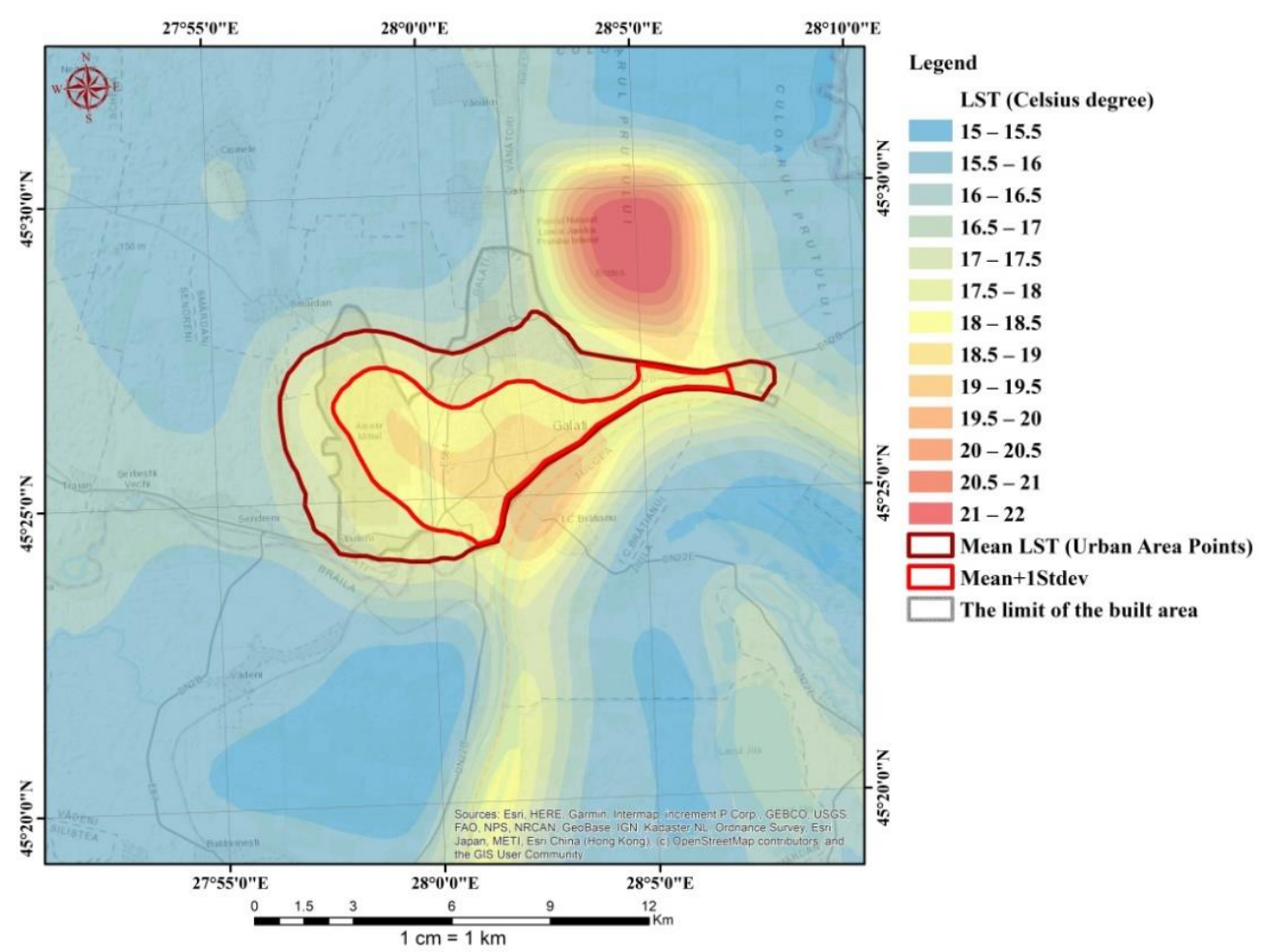

Figure 10. UHI limits (nighttime)

In fact, the warmer Danube waters from the vicinity of the city represent a result of the low mixing of waters of Siret and Danube after their confluence, but also of the Danube riverbed morphology. Therefore, as a direct consequence of this complex hydrological process we can consider that the Galați UHI, located near the Danube, is fuelled by the warmer air over the Danube during the summer nights. 
Average LST within Galati urban area may reach $19-21^{\circ} \mathrm{C}$ for nighttime observations, compared with $15-17^{\circ} \mathrm{C}$ in the bordering areas. As well, we remark a depletion of the industrial core of UHI during the night while the city center better conserves the characteristics of UHI.

For the nighttime, with the contribution of the largest water bodies specific for Danube river and Brates lake, only one UHI core develops. This UHI core can be observed on the NW-SE profile in the Figure 9 where LST mean values are highest over the Danube river and on the lowest terraces of the river $\left(17.0^{\circ} \mathrm{C}\right)$. The UHI core, fuelled by the warmth of water bodies, develops mainly over the residential and old part of the city. This core is also observed on the E-W and N-S profiles in Figure 9 with its peak at $17.5^{\circ} \mathrm{C}$, but also on the NE-SW profile where it shows a mean values at $17.5^{\circ} \mathrm{C}$ and represents the second peak of the temperature cross section. From the same cross section we observed that the warmest part of the Galați city and its surroundings is specific to the Brateș lake, but its position and the distance from the city center impede a major influence on geometry of the UHI core during the nighttime.

For each profile, we notice that the changing points are closely related to the land use categories and especially to built-up area characteristics. The decrease in LST from the inner city to its surroundings is not linear, meaning that the statistical test may return significant thermal differences between adjacent urban surfaces (e.g. continuous urban fabric, discontinuous urban fabric, industrial and commercial units, aquatic surfaces).

During nighttime UHI limit tends to be irregular, and average LST within the Galați urban area may reach $20-20.0^{\circ} \mathrm{C}$ for nighttime, compared with $15-16^{\circ} \mathrm{C}$ in the periurban areas. We should mention that the water bodies extend the UHI limit along the river in the southern part of the city. In this manner we can observe that the UHI central core analyzed by mean+stdev draws precisely the exact limit of the high build-up area of the Galați city (figure 10).

\subsection{Intensity of the summer UHI}

In general, UHI intensity is expressed by the thermal difference between values measured in the urban area, often at a weather station, and those measured in a neighbouring rural area that is not under the influence of UHI (Oke 1982, Oke et. al. 1991; Unger et al., 2001). For this work, the points/pixels specific to the urban area, the rural area, the agricultural areas, as well as the aquatic areas, were selected comparing them later (fig. 11).

Figures 11 and 12 show a comparison of the LST values in the urban area with those in the rural, agricultural and aquatic areas. For daytime observations, the most significant differences in LST appear between the specific points of the urban area and the water surfaces, followed by the rural and agricultural surfaces. The 
maximum monthly values are reached in July-August when the mean LST in urban areas overpass $35^{\circ} \mathrm{C}$ and remain below $30^{\circ} \mathrm{C}$ over the water surfaces. The most accurate image of the UHI intensity is given by the fact that the mean LST is by 2$2.5^{\circ} \mathrm{C}$ higher in urban than in rural area for all the summer months.

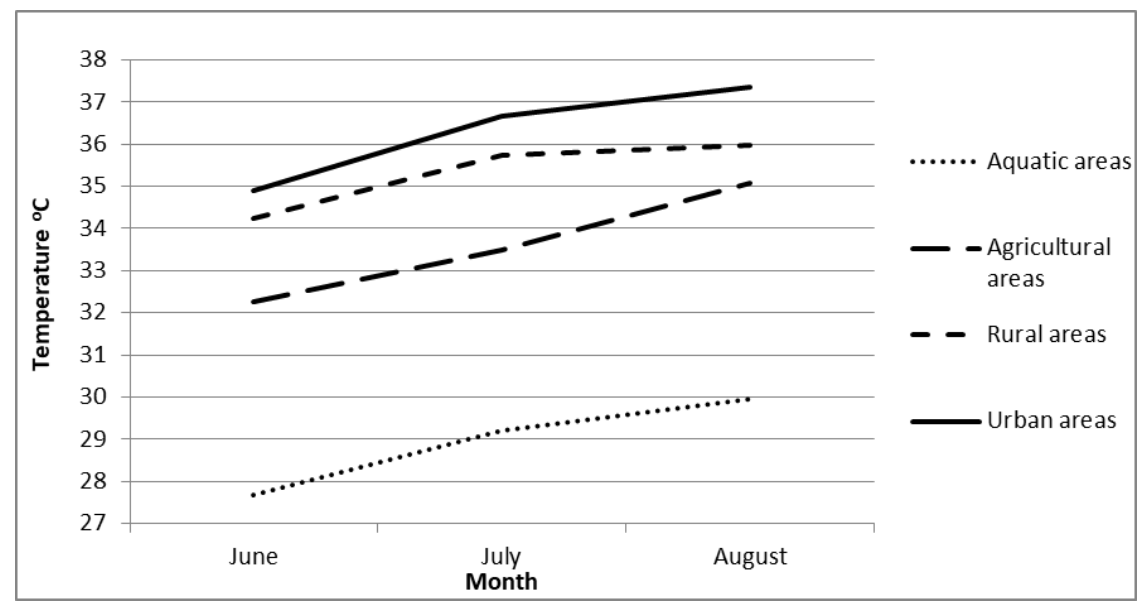

Figure 11 Daytime LST differences between urban, rural, agricultural and aquatic areas during summer in Galați

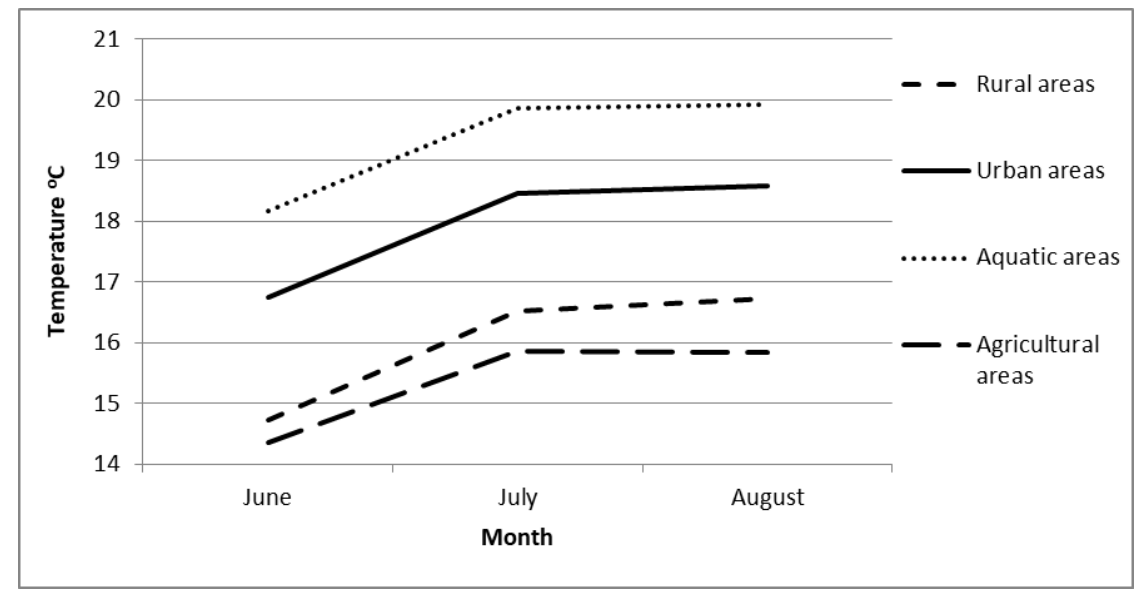

Figure 12 Nighttime LST differences between urban, rural, agricultural and aquatic areas during summer in Galați

For the nighttime observations, water surfaces have the highest LST values close to $20^{\circ} \mathrm{C}$ in July and August. LST differences indicating the UHI intensity are 
observed by comparing the urban area with those in the rural and agricultural areas $\left(1.5-2^{\circ} \mathrm{C}\right.$ in July and August).

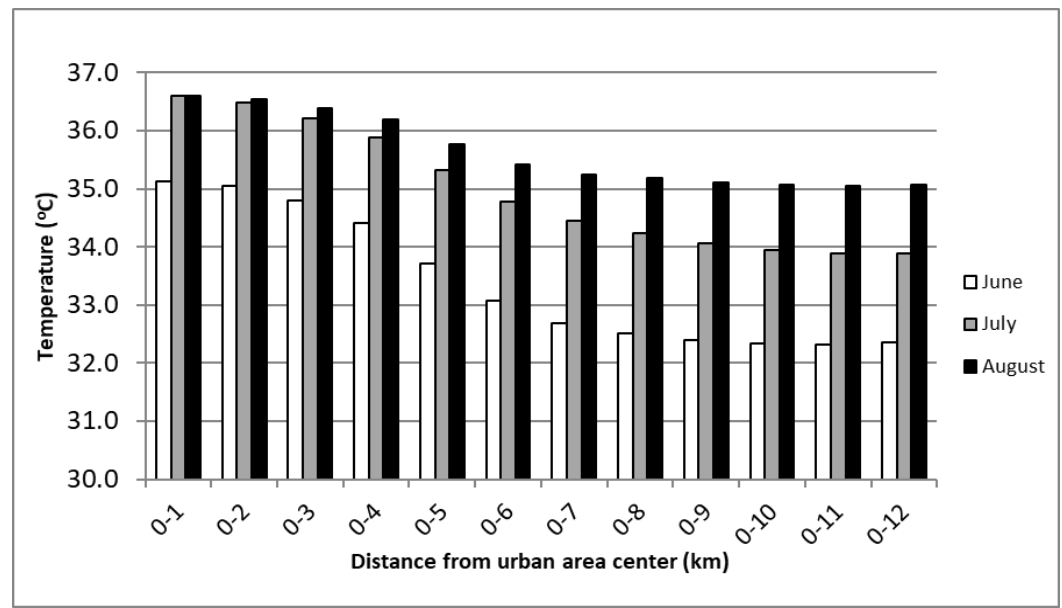

Figure 13 Daytime mean LST values $\left({ }^{\circ} \mathrm{C}\right)$ from city center $(0)$ to outer limit of the urban area until $12 \mathrm{~km}$ calculated for $1 \mathrm{~km}$ buffer zones

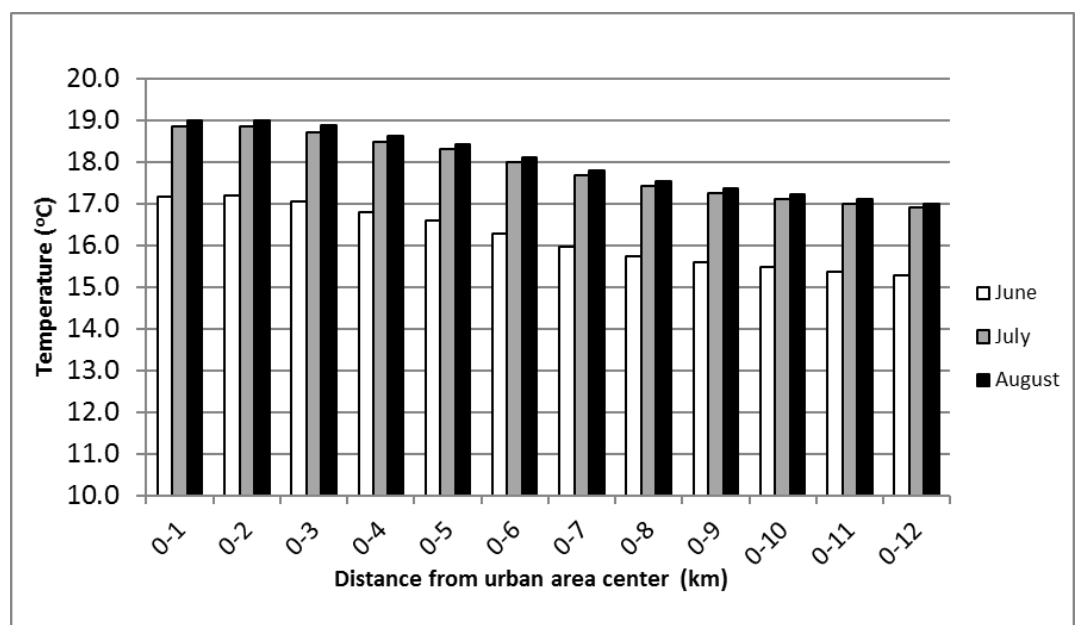

Figure 14 Nighttime mean LST values $\left({ }^{\circ} \mathrm{C}\right)$ from city center $(0)$ to outer limit of the urban area until $12 \mathrm{~km}$ calculated for $1 \mathrm{~km}$ buffer zones

In this regard we should underline that these LST values for the major land cover classes express the general thermal conditions during summer only for clear 
sky days and only for the satellite recording hours. When taking to account the overcast or cloudy days the conditions will be significantly different and in order to describe these conditions a network observation at ground level should be installed. Generally, we can observe also that June records the lowest monthly mean due to its highest amount of precipitation and higher levels of air humidity.

To indicate more clearly the intensity of the UHI, a series of buffer zones were designed, starting from the center of the urban area and up to $12 \mathrm{~km}$ away from it. This method indicates LST differences (fig. 13 and 14) as we move away from the inner city towards the periphery. During the summer months, LST values decrease with the distance from the inner city, as a direct consequence of UHI manifestation. This LST decrease from the city center to the periphery is higher during the daytime than during the night for all the months.

For the first buffer zone $(0-1 \mathrm{~km})$, the average LST for the summer months (daytime) is about $36.5^{\circ} \mathrm{C}$ in July and August and $35.0^{\circ} \mathrm{C}$ for June, while for the last buffer zone $(0-12 \mathrm{~km})$ the average LST is about $35^{\circ} \mathrm{C}$ in August and $34^{\circ} \mathrm{C}$ in July (figure 13). Using this method we can see that the intensity of UHI during the day is higher in June and weaker in August. This happens due to the fact that in August the temperature over the agricultural areas in the surrounding of the city is higher than in June due to advanced crop phenology. During the day the limit of the UHI is associated with a steep decrease of LST is between 5 and $7 \mathrm{~km}$ from the city center. This steep decrease is induced both by the combination between UHI thermal effect, but also by the cooler water surfaces of Danube river and Brateș lake. We can see the bands of maximum influence of the water body for daytime (fig. 4). Lake Brateș exerts a moderating influence on the UHI on a mean linear distance of about $1 \mathrm{~km}$. On a shorter distance we also notice the influence exerted by the Danube.

During nighttime the mean LST reaches its maximum $\left(19.0^{\circ} \mathrm{C}\right)$ for the first 3 buffers $(0-3 \mathrm{~km})$ and are quite similar for July and August. June follows the same pattern but it's $2^{\circ} \mathrm{C}$ cooler than the two other months. For the nighttime a steep decrease in mean LST is seen between 7 to $10 \mathrm{~km}$ from the city center. This time the body waters extend the area of high temperature imposed by the UHI.

\subsection{Land cover influence on the Galati city summer UHI}

The mean LST differences between continuous or discontinuous urban fabric are obvious, as well as the differences between these classes and those of industrial, permanent crops, arable land or water surfaces. Differences of about 1$2^{\circ} \mathrm{C}$ for daytime (figure 15) are observed by comparing the continuous urban fabric with the discontinuous one. The most significant differences for daytime appear between the industrial sector, continuous urban fabric, discontinuous urban fabric 
and water surfaces with an mean difference of $4-6^{\circ} \mathrm{C}$. As well, we can observe that the density of the urban areas is directly related to the LST.

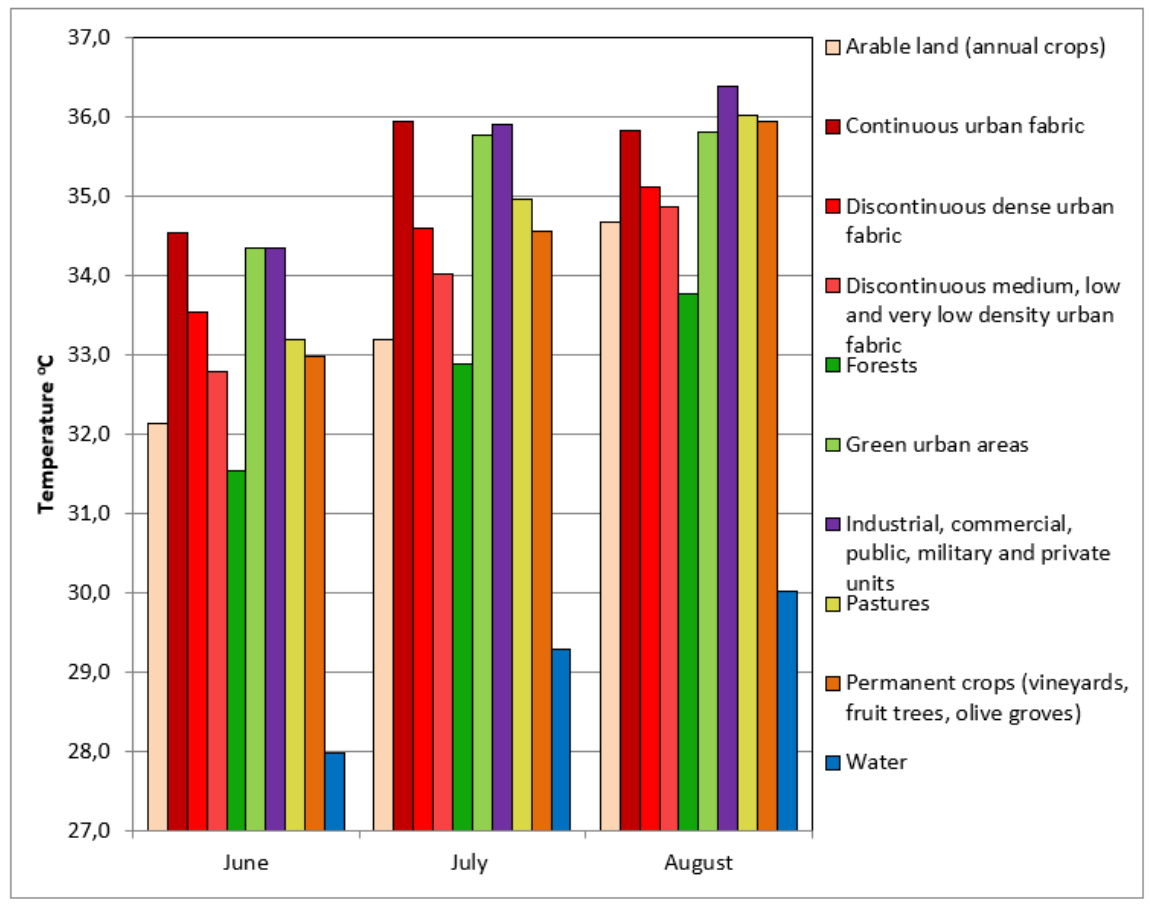

Figure 15 Summer mean LST values over land cover types over Galați city area (daytime)

Interestingly, we should observe that green urban areas are not cooler than the dense urban or industrial area from the UHI, despite the well known cooling effect generated by green areas in the city (Aram et al., 2019). Moreover, we can see that during the night the green area remain very warm. The explanation is given by the fact that the green area of Galați are located mostly on the low altitudes making them warmer during the day and near the water bodies making them warmer during the night.

For nighttime observations (figure 16), there are significant average temperature differences between water and urban surfaces. The role of urban builtup density is more pronounced during the night that during the daytime with the higher LST for dense urban area. In these regions the lack of ventilation caused by the high density of buildings impedes the cooling, keeping the highest valued of LST. The surface of water bodies reaches the maximum of all land use categories 
and it represents a source of warm air for the urban areas from their vicinity. We should underline that summing up the night and day conditions for Galati the overall effect of water surfaces is to cool the urban climate conditions as observed for other cities (Cheval et al., 2020).

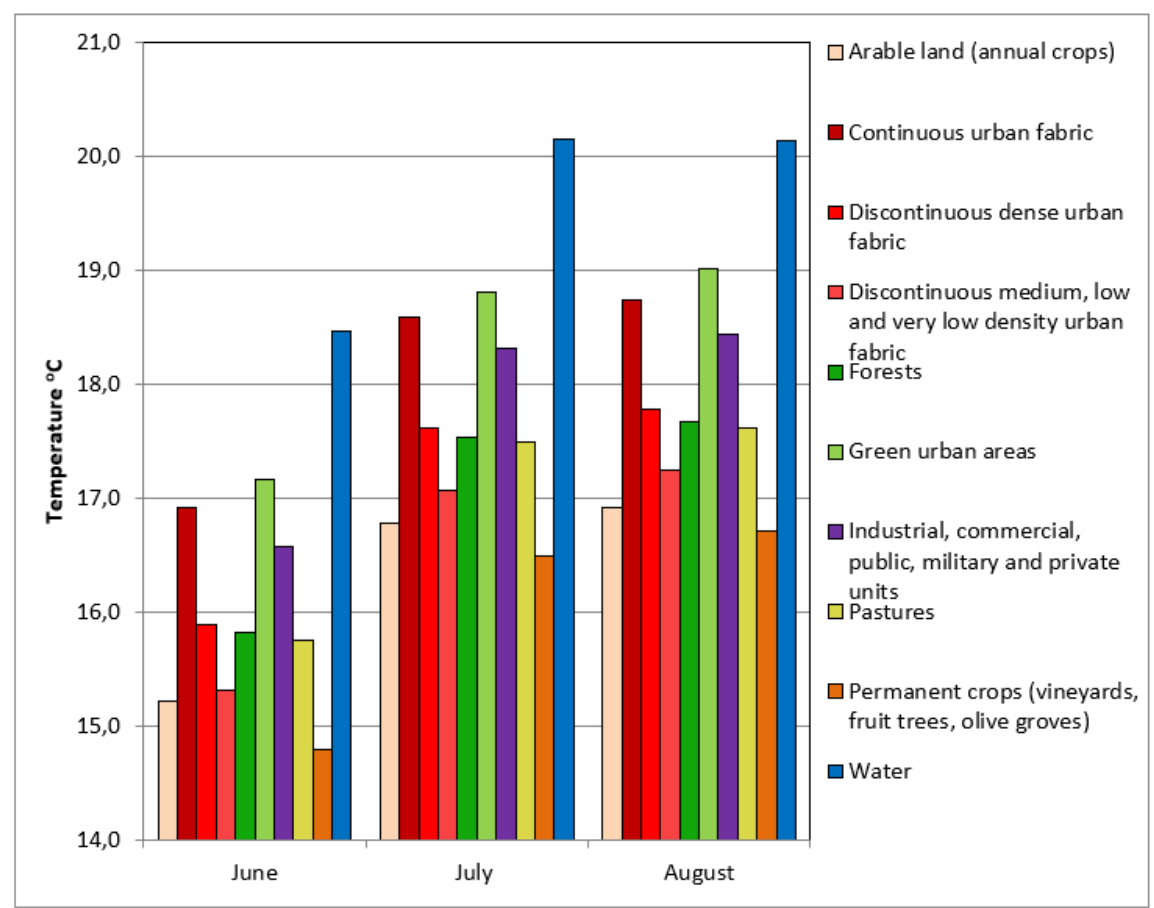

Figure 16 Summer mean LST values over land cover types over Galați city area (nighttime)

\section{CONCLUSION}

The current remote sensing analysis of Galaţi summer UHI proved to be a very relevant method for the highlighting the thermal differences between the inner city and its surroundings. Some constraints may be given by the weak temporal resolution imposed by specific meteorological features, such as cloud cover. Despite these shortcomings the satellite products lead to an accurate image of the UHI, both during the day and night.

Generally, we have observed that the highest intensity of UHI was recording during the daytime when the differences of LST between urban and rural area reaches $2-2.5^{\circ} \mathrm{C}$. During this time the UHI is formed by two cores, one located 
over the SIDEX industrial platform, while the second one is extended over the residential areas. During the night the structure of UHI is more simple and is most probably fuelled by the warmth of the Danube waters.

The UHI limit tends to be regular during the daytime and irregular during the nighttime. The irregular limit during the nighttime is influenced by the water surfaces that emit the heat stored during the day. Moreover, the influence of water surfaces on the UHI characteristics represents an important characteristic of Galați UHI. The main water surfaces that influence the UHI limits are represented by Lake Brates and the Danube. Due to their cooling effect during the day, the UHI is clearly delimited, while their warming during the night complicates the structure of UHI.

A further step towards a better description the Galați UHI should be represented by the necessity to develop a meteorological monitoring network in the city. Only this way, a comprehensive image on annual characteristics of UHI could be obtained.

\section{References:}

Arnfield AJ (2003) Two decades of urban climate research: a review of turbulence, exchanges of energy and water, and the urban heat island. Int J Climatol 23:1-26, doi.org/10.1002/joc.859

Apostol L, Alexe C, Sfîcă L (2012) Thermic differentiations in the Iaşi municipality during a heat wave. Case study: 8-20 July 2011. Pres Environ Sust Dev 6(1):395-404

Aram, F., Higueras E.G., Solgi, E., Mansournia, S., Urban green space cooling effect in cities, Heliyon, 5(4), 2019, doi: https://doi.org/10.1016/j.heliyon.2019.e01339

Basara JB, Basara HG, Illston BG, Crawford1 KC (2010) The impact of the urban heat island during an intense heat wave in Oklahoma City. Adv Meteor Article ID 230365, 10 pages, doi.org/10.1155/2010/230365

Cheval S, Dumitrescu A (2009a) The July urban heat island of Bucharest as derived from MODIS images. Theor Appl Climatol 96(1-2):145-153, doi.org/10.1007/s00704-0080019-3

Cheval S, Dumitrescu A, Bell A (2009b) The urban heat island of Bucharest during the extreme high temperatures of July 2007. Theor Appl Climatol 97:391-40, doi.org/10.1007/s00704-008-0088-3

Cheval, S., Popa, A.M., Șandric, I., Iojă, I.C., Exploratory analysis of cooling effect of urban lakes on land surface temperature in Bucharest (Romania) using Landsat imagery, Urban Climate, 34, 2020, doi: https://doi.org/10.1016/j.uclim.2020.100696

Copernicus Land Monitoring Service - Urban Atlas 2018, land.copernicus.eu/local/urban-atlas/urban-atlas-2018

Florea Cristian Tiberiu (2000) Clima orașului Galați de la înființarea stației meteorologice până în zilele noastre, Ed. Arionda. 
Gugiuman I, Cotrău M (1975) Elements of urban climatology with examples from Romania (book in Romanian). Edit. Academiei Române, București

Gabriel KMA, Endlicher WR (2011) Urban and rural mortality rates during heat waves in Berlin and Brandenburg, Germany. Environ Pollut 159:2044-2050, doi.org/10.1016/j.envpol.2011.01.016

Ichim P, Apostol L, Sfîcă L, Khadim-Abid AL (2015) Air temperature anomalies between rivers Siret and Prut in Romania. Pap Geogr Semin BDimitrie Cantemir ${ }^{\wedge}$ 40(1):47-56, dx.doi.org/10.15551/lsgdc.v40i0.05

Ichim P., L. Sfîcă, A. Kadhim, A. Ursu, V. Jitariu., (2018) Characteristics of nocturnal urban heat island of iaşi during a summer heat wave (1-6 of august 2017), doi.org/10.24193/AWC2018_29

Imhoff, M. L., Zhang, P., Wolfe, R. E., \& Bounoua, L. (2010). Remote sensing of the urban heat island effect across biomes in the continental USA. Remote Sensing of Environment, 114(3), 504-513, doi.org/10.1016/j.rse.2009.10.008

Jin, M., R.E. Dickinson, and D. Zhang, 2005: The Footprint of Urban Areas on Global Climate as Characterized by MODIS.J. Climate, 18, 1551-1565, https://doi.org/10.1175/JCLI3334.1

Leiqiu Hu, Nathaniel A. Brunsell, Andrew J. Monaghan, Michael Barlage, and Olga V. Wilhelm (2013) How can we use MODIS land surface temperature to validate long-term urban model simulations?

Macarof Paul, Florin Statescu (2017) Comparasion of NDBI and NDVI as Indicators of Surface Urban Heat Island Effect in Landsat 8 Imagery: A Case Study of Iasi, doi.org/10.1515/pesd-2017-0032

Mills Gerald, 2008, Luke Howard and The Climate of London, Weather - June 2008, Vol. 63, No. 6, doi.org/10.1002/wea.195

Nina Schwarz, Sven Lautenbach, Ralf Seppelt (2011) Exploring indicators for quantifying surface urban heat islands of European cities with MODIS land surface temperature, doi.org/10.1016/j.rse.2011.07.003

Oke TR (1973) City size and the urban heat island. Atmos Environ 7: 769-779, doi.org/10.1016/0004-6981(73)90140-6

Oke, T. R. (1982). The energetic basis of the urban heat-island. Quarterly Journal of the Royal Meteorological Society, 108(455), 1-24, doi.org/10.1002/qj.49710845502

Oke, T. R., Johnson, G. T., Steyn, D. G., Watson, I. D. (1991). Simulation of surface urban heat islands under 'ideal' conditions at night. Part 2: diagnosis of causation. Boundary Layer Meteorology, 56(4), 339-358, doi.org/10.1007/BF00119211

Patriche, C.V. (2009) Statistical methods applied in Climatology (book in Romanian), Publisher: Terra Nostra, Iaşi, Romania.

Rodionov Sergei (2004). A Sequential Algorithm for Testing Climate Regime Shifts. Geophysical Research Letters - GEOPHYS RES LETT., doi.org/10.1029/2004GL019448

Schwarz N, Lautenbach S, Seppelt R (2011) Exploring indicators for quantifying surface urban heat islands of European cities with MODIS land surface temperatures. Remote Sens Environ 115(12): 3175-3186. doi.org/10.1016/j.rse.2011.07.003 
Stewart, I. D. (2011). A systematic review and scientific critique of methodology in modern urban heat island literature. International Journal of Climatology, 31(2), 200-217, doi.org/10.1002/joc.2141

Sfîcă L., Ichim P., Apostol L., Ursu. A., (2017a) The extent and intensity of the urban heat island in Iași city, Romania, doi.org/10.1007/s00704-017-2305-4

Sfîcă, Lucian; Croitoru, Adina-Eliza; Iordache, Iulian; Ciupertea, Antoniu-Flavius. 2017b. "Synoptic Conditions Generating Heat Waves and Warm Spells in Romania."Atmosphere 8, no. 3: 50, doi.org/10.3390/atmos8030050

Tan J, Zheng Y, Tang X, Guo C, Li L, Song G, Zhen X, Yuan D, Kalkstein AJ LIF, Chen $\mathbf{H}$ (2010) The urban heat island and its impact on heat waves and human health in Shanghai. Int J Meteor 54:75-84, doi.org/10.1007/s00484-009-0256-X

Unger J, Sümeghy Z, Zoboki J (2001) Temperature cross-section features in an urban area. Atm Res 58:117-127, doi.org/10.1016/S0169-8095(01)00087-4

Voogt, J. A., \& Oke, T. R. (2003). Thermal remote sensing of urban climates. Remote Sensing of Environment, 86(3), 370-384, doi.org/10.1016/S0034-4257(03)00079-8

Wan Z., Zhang Y., Zhang Q., Li Z.-L. (2004) Quality assessment and validation of the MODIS global land surface temperature, International Journal of Remote Sensing, 25:1, 261-274, doi.org/10.1080/0143116031000116417

Wienert, U., \& Kuttler, W. (2005). The dependence of the urban heat island intensity on latitude - A statistical approach. Meteorologische Zeitschrift, 14(5), 677-686, doi.org/10.1127/0941-2948/2005/0069

Williamson, S. N., D. S. Hik, J. A. Gamon, J. L. Kavanaugh, and S. Koh (2013), Evaluating cloud contamination in clear-sky MODIS Terra daytime land surface temperatures using ground-based meteorology station observations, J. Clim., 26(5), 1551-1560, doi.org/10.1175/JCLI-D-12-00250.1

Yang, X., Leung, L.R., Zhao, N., Zhao, C., Qian, Y., Hu, K., Liu, X., Chen, B., 2017. Contribution of urbanization to the increase of extreme heat events in an urban agglomeration in east China. Geophys. Res. Lett. doi.org/10.1002/2017GL074084.

Zhang, J. Q., \& Wang, Y. P. (2008). Study of the relationships between the spatial extent of surface urban heat islands and urban characteristic factors based on Landsat ETM plus data. Sensors, 8(11), 7453-7468, https://doi.org/10.3390/s8117453

Zhengmin Wan, S. H., G. Hulley. 2015a. MOD11A2 MODIS/Terra Land Surface Temperature/Emissivity 8-Day L3 Global $1 \mathrm{~km}$ SIN Grid V006. NASA EOSDIS Land Processes DAAC. https://doi.org/10.5067/MODIS/MOD11A2.006

Zhengmin Wan, S. H., G. Hulley. 2015b. MOD11A2 MODIS/Terra Land Surface Temperature/Emissivity 8-Day L3 Global $1 \mathrm{~km}$ SIN Grid V006. NASA EOSDIS Land Processes DAAC. ORNL DAAC. 2018. MODIS and VIIRS Land Products Global Subsetting and Visualization Tool. ORNL DAAC, Oak Ridge, Tennessee, USA. Accessed March 07, 2019. Subset obtained for MYD11A2 product at $45.4336 \mathrm{~N}, 28.0295 \mathrm{E}$, time period: $2002-07-04$ to 2018-12-27, and subset size: $41 \mathrm{x} 41$ km. https://doi.org/10.3334/ORNLDAAC/1379

Zhengmin Wan, S. H., G. Hulley. 2015c. MYD11A2 MODIS/Aqua Land Surface Temperature/Emissivity 8-Day L3 Global $1 \mathrm{~km}$ SIN Grid V006. NASA EOSDIS Land Processes DAAC. 
Zhou, J., Li, J., \& Yue, J. (2010a). Analysis of urban heat island (UHI) in the Bejing metropolitan area by time-series MODIS data. IEEE International Geoscience and Remote Sensing Symposium (IGARSS 2010) (pp. 3327-3330).

Zhou, Y., Gurney, K., 2010b. A new methodology for quantifying on-site residential and commercial fossil fuel $\mathrm{CO} 2$ emissions at the building spatial scale and hourly time scale. Carbon Manage. 1 (1), 45-56, https://doi.org/10.4155/cmt.10.7

*** MOD11A2 product at 45.4268N,28.0089E, time period: 2001-01-01 to 2018-09-30, and subset size: 201 x $201 \mathrm{~km}$. https://doi.org/10.3334/ORNLDAAC/1379

*** MODIS land team (2011) Status for: land surface temperature and emissivity (MOD11)

*** ORNL DAAC. 2018. MODIS and VIIRS Land Products Global Subsetting and Visualization Tool. ORNL DAAC, Oak Ridge, Tennessee, USA. Accessed October 31, 2018.

*** Strategia de dezvoltare a municipiului galați 2016-2025 http://www.anpm.ro/documents/19877/31765021/STRATEGIE+DE+DEZVOLTARE +2016-2025_Mun+Galati.pdf/31c360db-c396-4d2e-ab34-20dd21e9581b

*** http://apmgl.anpm.ro/

*** https://doi.org/10.5067/MODIS/MYD11A2.006

*** https://doi.org/10.5067/MODIS/MOD11A2.006

*** https://daac.ornl.gov/cgi-bin/dataset_lister.pl?p=12

*** https://earthexplorer.usgs.gov/

*** https://modis.gsfc.nasa.gov/about/

*** https://climatedataguide.ucar.edu/climate-data-tools-and-analysis/regridding-overview

(C) 2020 by the authors. Licensee UAIC, Iasi, Romania. This article is an open access article distributed under the terms and conditions of the Creative Commons Attribution (CC BY-NC-ND) license (https://creativecommons.org/licenses/by-nc-nd/4.0). 